\title{
The NimbY Syndrome in Rural Areas. The Case of Poland. A Research Report
}

\author{
Karolina DMochowsKa-DUdek, Lódź, and Maria BEDNAREK-SZCZEPAŃSKA, \\ Warsaw [Warszawa]*
}

with 6 figures in the text

\section{Content}

Summary .99

1 Introduction 100

2 Research concept and methods. 102

3 The spatial dimension of the 'NIMBY' syndrome.... 104

4 Legal and administrative conditioning of the locating of unwanted developments.

5 The social dimension to the 'NIMBY' syndrome 112

6 Conclusions... 117

7 References 118

\section{Summary}

This article presents the key results of work within the framework of a Polish National Science Centre grant, which was carried out in rural areas and small towns in Poland in the years 2013-16, and was concerned with the so-called NIMBY syndrome. The latter is associated with socio-spatial conflicts and takes in a certain group of interlinked events and behaviours relating to plans or decisions as regards the locating of new unwanted or undesirable developments. NIMBY-type buildings or items of

* Karolina Dмochowska-Dudek, PhD., University of Łódź, Department of Regional and Social Geography, 90-131 Łódź, ul. Kopcińskiego 31, Poland; email: karolina.dmochowska@ geo.uni.lodz.pl; Maria Bednarek-SzczePańska, PhD., Polish Academy of Sciences, Institute of Geography and Spatial Organization, 00-818 Warszawa, ul. Twarda 51/55, Poland; email: bednarek@twarda.pan.pl 
infrastructure are regarded by local communities as potentially harmful, even if their installation and operation is needed by society as a whole (hence the original phrase "yes, but Not In My Back Yard"). The work described here has sought to consider the spatial differentiation and distribution of such NIMBY conflicts in Poland's rural areas and small towns, the legal and administrative conditioning underpinning the locating of such unwanted new developments, and the conditioning and specific nature of the NIMBY syndrome in terms of its social dimension.

\section{Introduction}

Socio-spatial conflicts encompass a series of phenomena associated with disputes over the management and functioning of defined sites. It is exceptionally common for conflicts of this kind to be associated with the so-called 'not in my back yard' ('NIMBY') syndrome, whereby a local community is fully aware that an installation of overall benefit to society is needed, but feel nevertheless that it should be located away from their immediate vicinity. The term itself made its way into relevant Englishlanguage scientific literature in the 1980s (LivEZEY 1980; BuRninghAm et al. 2006), and is taken to embrace local protests of various kinds, in practice directed most often at elements of technical infrastructure, be these roads, landfill sites, plants for the segregation and incineration of waste, wastewater treatment plants, telecom masts, wind farms or power stations, most especially if nuclear. Nevertheless, the term and the phenomenon - may also extend to reactions to social or health facilities, like psychiatric hospitals, rehabilitation centres and prisons; or even to more-everyday production facilities or factories.

A wealth of literature has now been devoted to the characterising of NIMBY-prone installations or infrastructure in various different countries. Statistically, it would seem that the issue arises most often in connection with landfill sites (i.a. LeVINSON 1999; FREDriksson 2000; Minehart 2002; RAHARdyan 2004; CAPLAN et al. 2007), as followed by wind farms (i.a. Devine-Wright 2005; Wolsink 2000; Bell et al. 2005; van Der Horst 2007) and various services like welfare centres for the homeless, hospitals, and centres for the mentally ill or the treatment of addicts (TAKAHASHI \& DEAR 1997; Lesbirel \& Shaw 2000; Schively 2007; Hermansson 2007). Numerous studies on the NIMBY syndrome have been carried out in the USA, Canada, Western Europe, and such Asian countries as Japan, South Korea or Taiwan. Overall, these represent a wealth of output that can be used to seek rules and principles underpinning the phenomenon, given an assumption that the main common features here are augmented by certain 'national' characteristics reflecting different states' or societies' historical, cultural, political, economic or legal conditioning. It is also for this reason that an analysis of the NIMBY syndrome can encourage further discussion and comparison of 
the mechanisms governing the phenomenon in different parts of the world, shaped by different conditions.

In Poland, work on the NIMBY syndrome has only a relatively short history, with this fact in turn reflecting the specific conditioning present in this country. Until the 1990s, the previous regime's official line was that spatial planning or physical development did not generate any social conflicts at all, given the way that a centrallyplanned economy had no place for the kind of ad hoc private initiative or investment that could generate controversy. Beyond the bold and dogmatic claims, the truth was that anybody who was unhappy and chose to raise his/her voice in protest, could rather readily be silenced. Hence, it cannot be said that conflict was non-existent. Indeed, thanks in particular to increasing environmental awareness in Poland, the 1980s did see dissatisfaction expressed, most especially in regard to the most environmentallyburdensome plants of heavy industry. Nevertheless, the academic world left the social context to this subject matter well alone, focusing - if at all - on the analysis of 'collisions' over spatial planning reflecting such conflict-generating choices of designated function as industrial versus residential versus tourist-related (GROCHOLSKA 1980, 1986; KoŁODZIEJSKi 1982a, 1982b).

Needless to say, Poland's reattainment of 'free country' status in 1989 ensured that the 1990s witnessed a dramatic increase in (the visibility of) conflicts regarding the locating of infrastructure. Furthermore, systemic change had taken place, and a more-enfranchised society now coincided with a full and abrupt injection of freemarket principles into the Polish economy. New investment and new developments proceeded apace, and all the more so as it became clear that Poland would soon be acceding to the European Union. A breakneck pace was called for given the degree to which the economy lagged behind (in terms of infrastructure, as in every other sense), but the inherited system of spatial planning was of course highly imperfect and in practice both cumbersome and ineffective. The aforesaid growth in awareness of environmental issues combined with greater activity on the part of civil society to ensure that a great many new developments - planned or implemented - were protested against, more often than not with adoption of the familiar approach of "yes, but ... not in my back yard!"

Particular Polish 'venues' in which the NIMBY syndrome might be seen to concentrate are the country's rural areas. These were naturally places receiving large amounts of investment, given the need to reduce developmental disparities between urban and rural areas. Many of the attendant developments (like wastewater treatment plants and new roads) were worthy and well-meaning enough. On the other hand, the rural areas around large cities have represented - and have been viewed as - natural reserves supporting the development of cities, which may seek to unceremoniously 'shove' more burdensome new developments beyond their boundaries. Things become still more complex when it is recalled how the areas of suburbs and satellite towns in question have specifically come to be inhabited by those able to escape from the dirt 
and hurly-burly of the centres of metropolises, in search of quiet, cleanness and contact with nature.

All of this ensures that rural areas - and in particular those just beyond city limits - are places in which a battle for (the value and quality of) space is being fought, and between users whose interests are entirely in opposition.

It was for these kinds of reason that research on the NIMBY syndrome in Poland's rural areas was commenced with in 2013, on the basis of a grant awarded by the National Science Centre. The Project had as its main goal the identification of the conditioning, specifics and consequences of conflicts centring around unwanted new developments, by way of a first cross-cutting study taking in the whole of Poland. Presented here are key results from the work carried out in this regard, as it concerns the socio-spatial characterisation of the NIMBY syndrome in the country's rural areas.

\section{Research concept and methods}

Data on local-community protests against burdensome new developments are not brought together in the context of Poland-wide statistical research carried out by the Central Statistical Office [Główny Urząd Statystyczny], not present in Censuses, and not compiled either by any other central or regional authorities or scientific/academic centres. In the face of such a lack of statistical data a difficulty with recognising the presence and diversity of spatial conflicts nationwide was encountered from the very outset. Hence a decision taken to confine the research seeking to identify NIMBY conflicts in Poland's rural areas to searches through press-archival materials concerning the 01.2007-03.2014 period. The Polish press was thus searched for reports describing groups of inhabitants' opposition to new developments being sited close to their places of residence. The search took in a total of 48 titles of local or regional reach. However, utilisation was further restricted to articles accessible in online archives (of either paidfor or free access) covering the said years 2007-2014 inclusive. Circulation was in fact a further factor, in the sense that - for any given area in which two press titles were available, it was the one printed in more copies - and hence deemed to be of greater significance in the given area - that was selected for study. The work took in both rural areas as such, and small country towns of up to 25,000 inhabitants.

The archival search guided in the above manner proved capable of identifying 499 conflicts, taking place in 404 of the local authority areas at gmina level into which Poland is divided. This number represents $18.6 \%$ of all Poland's rural or urban-rural gminas. The main goal of the work was to provide a nationwide depiction of any spatial differentiation that might characterise Poland's NIMBY conflicts.

A further stage to the work entailed the selection of particular gminas in which online surveys on the NIMBY syndrome were carried out, in relation to the local 
officials responsible for spatial planning and physical development, and hence for decisions on the locating of new developments. Such online surveys in fact embraced some 116 of Poland's gminas, from among the 404 identified in the previous stage of the work. Among other things, the answers provided by survey participants offered an insight into the conditioning of the legal and administrative decisions taken in respect of controversial new developments.

The study's last stage entailed a detailed case-study analysis based on the data from questionnaires and interviews run in respect of local inhabitants involved in just nine of the conflicts under study. This research focused on conflicts meeting criteria as regards: (1) representativeness as regards subject matter (the conflicts selected relating to the kinds of new developments most often protested against); (2) location (with cases chosen to represent both peripheral and suburban areas, with each case referring to a locality in a different one of the 16 province-regions or voivodships into which Poland is divided administratively, and with all the country's main historical regions being taken into consideration); (3) date of conflict (work was confined to conflicts breaking out after 2008, as it was considered that by now the details of events further in the past would have tended to fade from - or become blurred in - the memories of respondents).

A total of 1017 questionnaires were run in the localities under study, with 820 involving opponents of given new developments. In turn, the interviews referred to above - around 30 in number - were more in-depth, and were addressed to the main players in given conflicts (i.e. leaders of local communities, including heads of villages and so on). The participation of opponents in the research did not offer a true reflection of the attitudes taken to a new development by local communities. However, given the aim of the Project, an access-related choice of samples was used to ensure compliance with the criteria that $80 \%$ of interviews be with opponents (given that the opinions of this group were most important), while $10 \%$ each were representative of supporters and those to be regarded as neutral, whose question-answering was confined to certain questions only, and served as a control in respect of the opponents. Notwithstanding the assumptions adopted as regards comparable numbers of questionnaires in respect of each conflict (at least 110 with opponents in each case), the breakdown in the numbers of respondents from the different localities does differ. This was affected by the sizes of the localities studied (ranging between 400+ and nearly 12,000 inhabitants), as well as the difficult and controversial subject matter of the interviews, which was often reflected in a negative attitude to those running the interviews, who tended to be treated with some suspicion and mistrust by inhabitants.

The material collected was made subject to analysis using both quantitative and qualitative methods, with this allowing the specifics of the NIMBY syndrome to be determined, and account taken of factors and levels of activity of NIMBYists, the effects of their actions and their social profiles. 


\section{The spatial dimension of the 'NIMBY' syndrome}

The results obtained from the press search relating to the 2007-2014 period support the claim that the NIMBY syndrome is very widespread in rural areas and small towns across Poland. In each of the country's 16 province-regions it proved possible to identify between 10 and several tens of conflicts revolving around various kinds of unwanted new development. Furthermore, the developments protested against were shown to vary quite markedly in terms of function, size of object, type of investor and scale and nature of impact. By reference to Poland's classification of economic activity (PKD), they were assigned to 13 categories, which in turn corresponded to three basic types of infrastructure, i.e. economic, technical or social.

A specific feature of the NIMBY syndrome in Poland's rural areas and small towns is a decided (70\%) prevalence of items of technical infrastructure among the new developments subject to protests of the NIMBY kind. Given the 'intensive' and often-burdensome nature of new developments involving technical infrastructure, it is not surprising that conflicts are generated markedly more often by these than by other basic types of infrastructure. This largest group comprising no fewer than 351 items of technical infrastructure including those associated with energy generation and supply (power plants, biogas plants and elements of transmission networks), the supply of water and management of wastewaters and wastes (water pipelines, wastewater treatment plants, landfills and facilities for the sorting and incineration of wastes), transport and storage (including roads, rail lines and airports), telecommunications (masts for the mobile phone networks) and national defence (development of infrastructure serving the US anti-missile shield located on Polish territory).

A total of 126 items of economic infrastructure proved controversial enough to generate conflict. These could be sub-divided into ones associated with farming and fisheries (pig farms, poultry sheds, fur farms and bases for fishing), with mining and mineral extraction (i.a. coal mines and sites for the extraction of oil, natural gas and metal ores), with industry and construction (factories and plants organised by types of production) and with trade and services (commercial centres, installations connected with the supply of gastronomy, residence and cultural activity, sport and recreation). The kinds of new development least well represented among NIMBY protests in rural areas and small towns are items of social infrastructure, of which there were just 22 examples, relating to psychiatric hospitals, rehabilitation centres, cemeteries and crematoria, prisons and animal shelters.

Around $90 \%$ of the objects against which the opposition of local communities was focused fell within the seven categories of energy generation and supply, transport and storage, the supply of water as well as wastewater and waste management, agriculture and fisheries, telecommunications, industry, and mining and mineral extraction (Fig. 1). In the light of such results it is these kinds of activity that need to be regarded as the most conflict-generating in rural areas. 
Figure 1: NIMBY objects by category

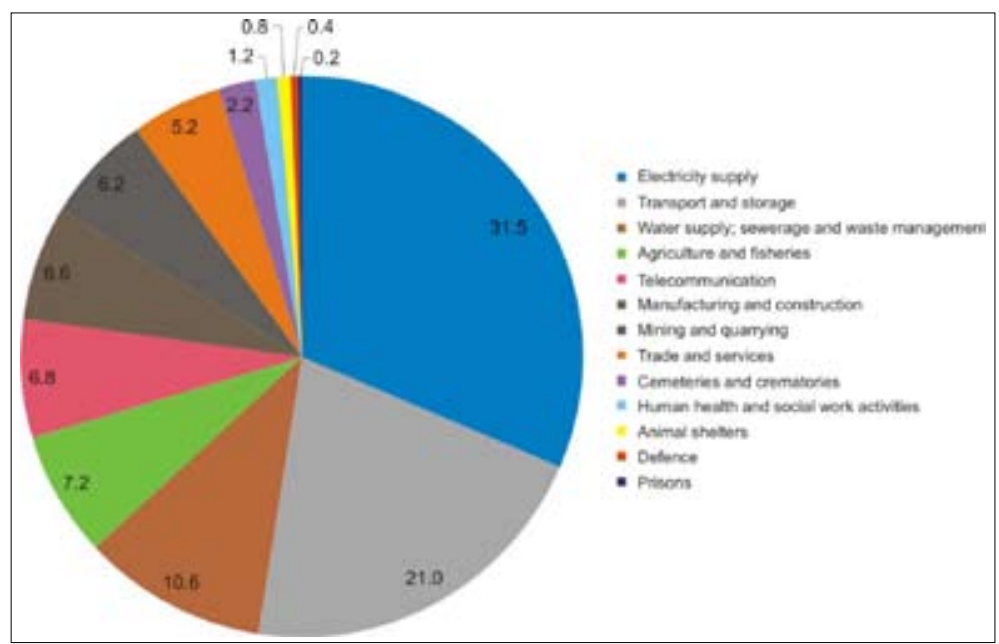

Source: authors' own elaboration

There were certain identified regularities when it came to the distribution of observed conflicts across the country. Concentrations of local-authority areas (gminas) in which conflicts arose were found to be present in Pomerania [Pomorze], northern Masovia [Mazowsze], the Suwałki region and Podhale. However, the most visible accumulation of NIMBY-type conflicts is present in the hinterlands of large cities. Conflicts in suburban rings around the majority of cities with more than 100,000 inhabitants were identifiable. In turn, the greatest densities of conflicts expressed per $1,000 \mathrm{~km}^{2}$ area were present in the vicinities of Poznań, Warsaw [Warszawa], the TriCity (Gdańsk-Gdynia-Sopot), Wrocław, Opole, Kielce and Rzeszów, as well as in the belt between the Silesian and Cracow [Kraków] agglomerations (Fig. 2). In analysing the distance of NIMBY objects from large urban centres, a map was produced with equidistant lines $10 \mathrm{~km}$ from the centroids of cities, before the numbers of NIMBY objects in particular zones was counted. The results of the analysis make it clear that over $40 \%$ of all conflicts (233 in total) are concentrated at distances up to $30 \mathrm{~km}$ from large cities. A further $40 \%$ of the total were associated with the zone $30-60 \mathrm{~km}$ out, while just $20 \%$ had arisen more than $60 \mathrm{~km}$ out from a city (Fig. 3). This is also to say that, the closer one is to an urban centre, the greater the number of undesired new developments that are present. 
Figure 2: Density of NIMBY objects

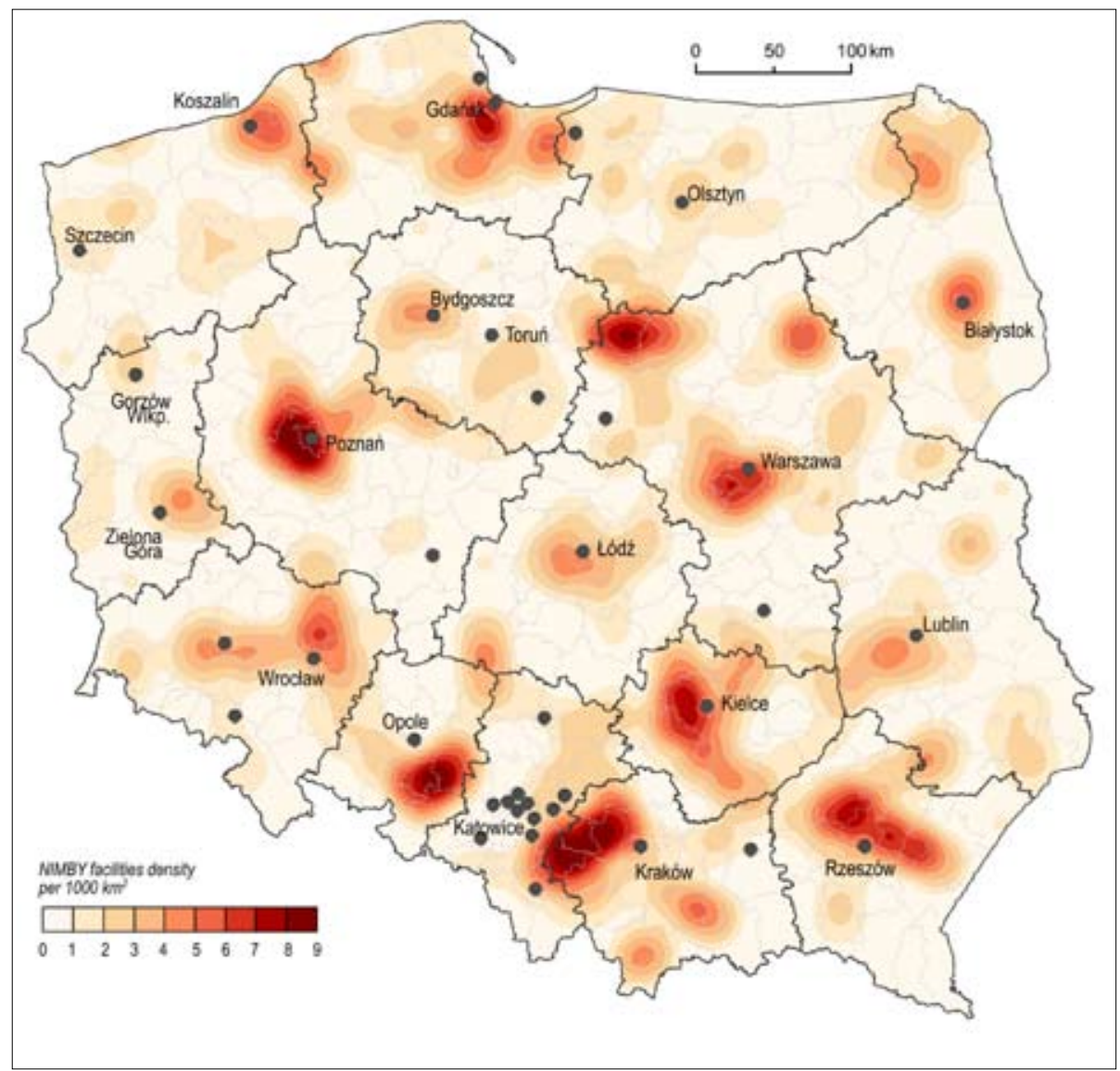

Source: authors' own elaboration

A set of factors ensure that areas in and beyond city suburbs ${ }^{1}$ are particularly likely to see conflicts emerge as regards the locations of new developments. Large cities seek to 'export' to their edges certain burdensome items of municipal or social infrastructure for which there is just no room in the city proper. However, the areas in question are already characterised by ever higher population density and densities of built-up areas. This means ever smaller areas available to take infrastructural items

1 The assumptions adopted were that 'suburban areas' (or, somewhat more precisely in English-language terms, 'areas surrounding cities') are rural areas immediately adjacent to cities whose populations exceed 100,000 . In contrast, 'peripheral areas' are remaining rural areas not included among the above, while 'small towns' are ones with fewer than 25,000 inhabitants, irrespective of their locations in respect of large cities. 
essential if both the nearby large city and the location area itself are to function (see also: WósciK et al. 2014).

Figure 3: Number of NIMBY facilities within concentric rings at $10 \mathrm{~km}$ intervals, surrounding large cities

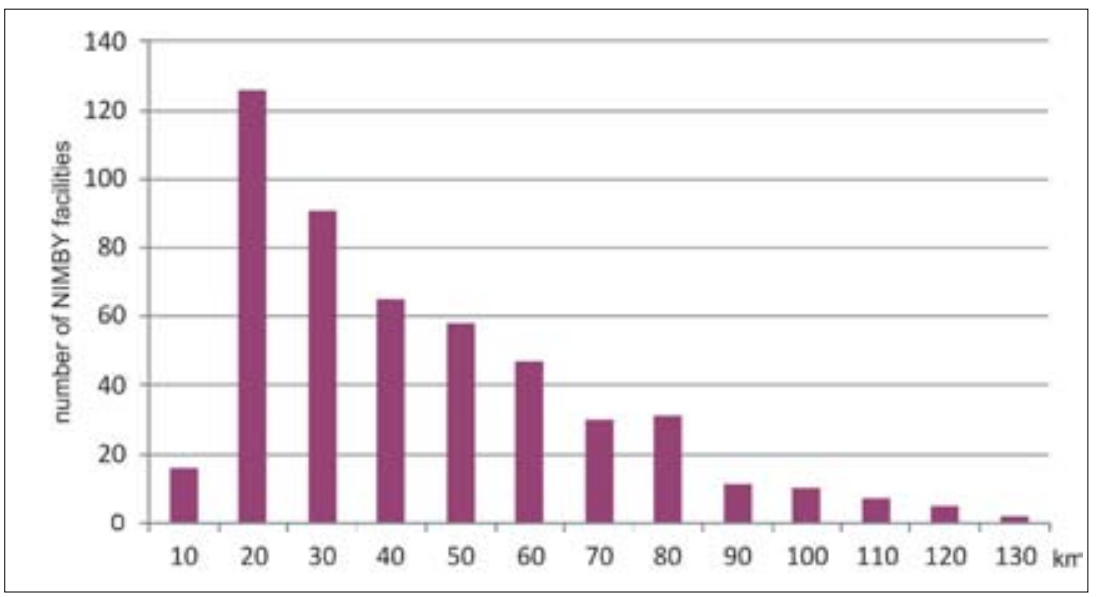

Source: authors' own elaboration

Further relevant factors concern the aspirations and characteristics of the communities now (and increasingly) inhabiting the areas surrounding cities. Here there is rapid growth in numbers of new inhabitants, who have deliberately moved beyond the continuously built-up area of the large cities in search of better living conditions. Such people certainly did not relocate only to have installations burdensome on account of the noise or pollution, etc. that they generate located in their immediate vicinity, and so are obvious and vocal opponents of such proposals.

More generally, it is significant that, compared with other rural areas, those on the edges of cities have a specific demographic structure in which the levels of education and social activeness are both high (WÓJCIK 2013; BAŃSKI \& CZAPIEWSKI 2009; RosNER $\&$ STANny 2007). To a great extent, the inhabitants here are young, well-educated and possessed of a certain citizen's savoir faire. This encourages them to resort to collective protest action in the face of new developments they regard as unfavourable. Areas on the edges of cities are the main places in which conflicts tend to centre around developments in the transport and storage categories (these categories accounting for $33 \%$ of conflicts in such areas).

The ever-greater need for the roads taking traffic into and out of large cities be remodelled, and or new bypasses constructed, obviously comes into conflict with the interests of those inhabiting rather densely-populated areas of the city suburbs and 
immediate surroundings. Causes of conflict here are also in fact very diverse. The ratio between numbers of conflicts and numbers of types of installation generating conflict assumes a much lower value here than in peripheral areas.

Small towns resemble the suburban areas when it comes to the breakdown of undesirable new developments into different types. In this case, the developments provoking a NIMBY response that were described most often in the press were associated with transport, with this sphere accounting for $28 \%$ of all the conflicts capable of being associated with people in small towns. However, the diversity of sources of conflict was again high in these areas. Indeed, the ratio of number of conflicts to number of types of conflict-generating development took on even slightly lower values than in the case of the edges of cities. These results come as no major surprise, given that both small towns and the suburban areas are characterised by a higher level of functional diversity than peripheral areas.

Peripheral areas were characterised by a marked dominance of conflicts connected with power supply. Developments in this category accounted for $42 \%$ of all conflicts in this type of area. Wind farms prevailed as causes of protect, and, obviously, these deliberately tend to be located far from large urban centres, ensuring a concentration in peripheral areas. Biogas plants generate using wastes from farming, hence it is obvious that these kinds of developments are also located in peripheral agricultural areas.

Analysis of the spatial depiction of NIMBY conflicts - as broken down by basic type of infrastructure - makes it clear that protests against items of technical infrastructure detailed in the regional press were scattered fairly evenly across Poland. In contrast, developments involving economic infrastructure were rather more likely to generate conflicts in central and western parts of the country than in the east. This may be connected with the overall spatial distribution of economic activity in Poland, given that this is well known for being more limited in eastern regions. It was also more common for economic infrastructure to provoke NIMBY conflicts in suburban areas and small towns than in peripheral areas. In contrast, elements of social infrastructure - which were rarely sources of conflict anyway - were of the most limited, marginal significance in peripheral areas (Fig. 4). This kind of finding was only to be expected, it being obvious that this type of infrastructure more often comes into existence in the more densely populated suburban or urban areas, where it is capable of generating numerous protests. 
Figure 4: NIMBY objects by type of infrastructure in suburban, peripheral areas and small towns

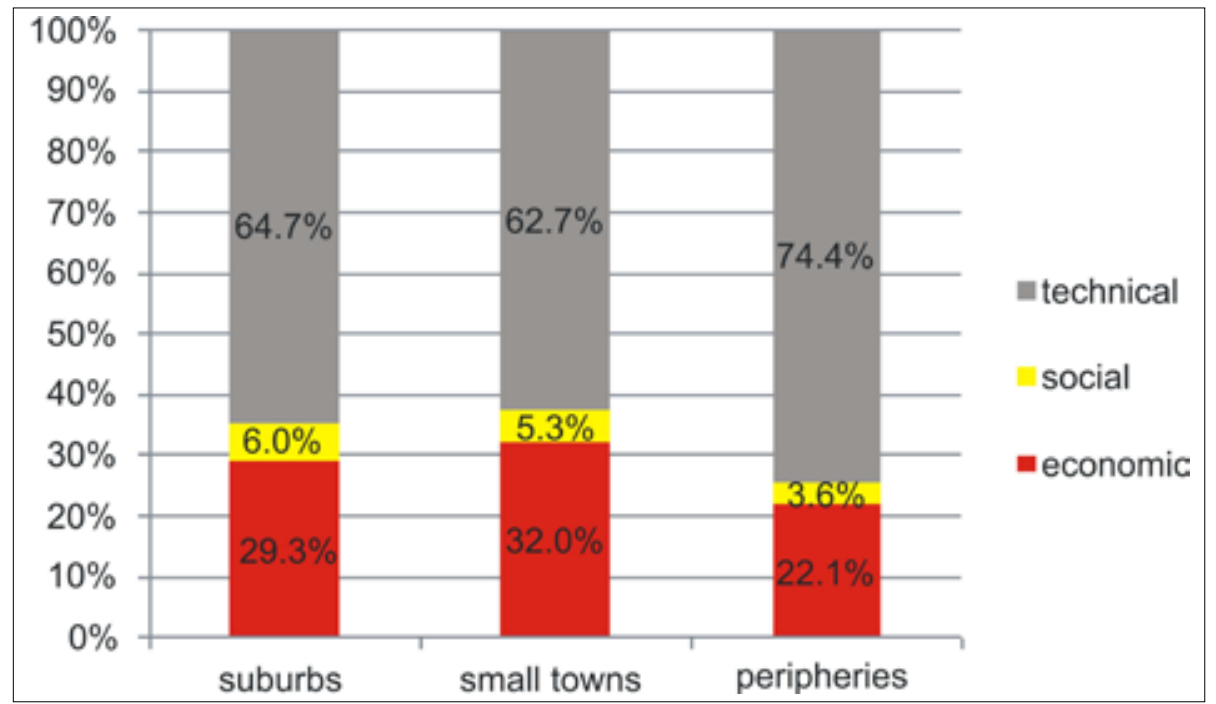

Source: authors' own elaboration

\section{Legal and administrative conditioning of the locating of unwanted developments}

New developments in Poland are located in two alternative ways, i.e. on the basis of a Local Plan, or - should such a plan be lacking - by virtue of a Decision (establishing building conditions or establishing the location of a development for a public purpose). Theoretically, in line with the intentions of the legislator, the locating of a new development by virtue of a Decision ought to be the exception to the rule, but this is not the case in practice. Furthermore, the use of location Decisions does much to limit the possibilities for a local community to influence the investment process. In this case, the role of the community is confined to the possibility for immediate neighbours of a planned development to appeal against a decision. As Groeger $(2009$, p. 86) notes: "the familiarity with legal regulations present among the public is very limited, while there are only 14 days to lodge an appeal, with the result that it is common for such doubtful determinations as regards the designation of land and building parameters to pass through without active public participation. This is a very dangerous situation where spatial planning is concerned." 
In the 166 gminas studied, around half (49\%) of the controversial new developments were to have (or did) come to fruition without the benefit of a Local Plan. In turn, only $25 \%$ of those protested against were to have been located by virtue of a Plan in force. In the remaining cases, either a Plan was lacking, or it was to be drawn up with a planned development in mind, or a Plan existed but was to have been amended in relation to the new development. Overall, this indicates that, in three out of four cases of location conflict analysed, inhabitants were basically surprised by the planned intention to pursue a new development. This is effectively what happens where a Local Plan is lacking and the management of land is thus unpredictable, or else where there is a Plan in place, but made subject to deliberate amendment to make a controversial new development possible. In short, it is only when and where a development is located on the basis of an existing Plan that inhabitants know - 'more or less' - what they can expect in the given area.

There is no question that the absence of such a Plan encourages the breaking out of conflicts over location. What is more, where a controversial new development is to be located by virtue of a Decision, it is more common for inhabitants to begin protesting at the last stage of proceedings (following the Decision relating to the environment), as opposed to when the location is to take place in accordance with a Plan. In almost half of the conflict cases in which a Local Plan was first drawn up or amended in line with a given new development, the activity on the part of the NIMBYists began at the stage of work on the Study of Physical Development Conditioning and Directions or Local Plan; i.e. at a stage that guaranteed participation in the elaboration process.

This possibility of participating in the elaboration of a Plan through the submission of applications or remarks is guaranteed by statute, though local authorities are not obliged to take account of the proposals they contain. And should no account be taken of submissions, those delivering them are not able to either appeal against or submit a complaint in regard to a solution unfavourable to them. Given such a legal situation, it becomes exceptionally important for a local authority to be ready and willing to seek an understanding and/or compromise, to engage in dialogue and above all to inform the local community of planned amendments as early as possible. As A. KopeĆ (2009) writes, good practices entail non-statutory public consultations, for example entailing the presentation of a draft Plan to inhabitants, prior to the agreements and opinions stage.

A very important issue revolves around this very aspect, namely the stage of the activity and procedures leading to the location decision as regards a new development at which the local community first learns of the planned new building of an item of infrastructure, and begins to pursue activity with a view to blocking implementation. From the inhabitants' point of view, the sooner they find out, the greater the chance that an influence can be exerted on the course the matter takes. The stages involved can be assigned to three broader phases. The first (initial) phase is one in which the investor appears, and makes its intentions known, but in which no action is yet taken on the part of the administration. There is then a subsequent middle phase in which work is 
undertaken to amend the Study of Physical Development Conditioning and Directions or Local Plan, and/or for an environmental impact assessment to be carried out. The final phase is then assumed to be that following obtainment of the Environmental Decision. ${ }^{2}$ By this time, the local community has limited chances to exert either a blocking or modifying influence on a planned new development. The Environmental Decision is binding as regards the Decision on building conditions and site management [Decyzja o warunkach zabudowy], while the latter is of key importance to the Planning Permission (permit to build). And where a Local Plan exists, the Permission must be in line with this.

The work carried out to meet the needs of the present study shows that it was in just $13 \%$ of cases that inhabitants began action targeted against the location of a new development during the aforementioned first phase. Most often (in $63 \%$ of cases), this kind of activity was commenced with at the stage of amendment of the Study or Plan, or else in the course or proceedings connected with an environmental impact assessment. At these points, inhabitants can submit remarks and applications, and thus participate in the decision making process in a meaningful way. However, in no fewer than $24 \%$ of cases, local communities only began to protest against a planned new development when the investor was already in possession of the Environmental Decision. Indeed, among these, half of all protests began after Planning Permission had already been received. This makes it look very probable that, in a quarter of the conflict situations analysed, inhabitants only learnt at a very late stage about plans for development, or only realised at that point what threat might be associated with them.

In conflicts over the locating of new developments, inhabitants taking up a stance in opposition to proposals often express their dissatisfaction at having heard about such plans too late. The media reporting on situations of this kind tell this story repeatedly. It can be seen to have several causes, but foremost among these is the fact that it may not necessarily be in the interests of local authorities supporting a new development to have a larger number of local inhabitants know about it. It is true that they take care to comply with statutory requirements as regards the posting - in the required places and at the right time - of information on proceedings being run. However, this does not mean that these are particularly effective ways of reaching persons potentially interested. The statutory provision concerning public consultations is so broad that superficial fulfilment of the requirement does not cause local authorities even the slightest problem (SIEMIŃSKi 2007).

In the second place, the procedures leading to the locating of a new development are so enigmatic and complex for the lay person, that even when the posting of such information is noted, inhabitants do not usually know how they should (or are able to) react, and what their potential influence on the course of events can reasonably be. They thus feel simultaneously surprised, underinformed and ignored.

2 Among the cases analysed there were only a very few developments for which an Environmental Decision was not required. 


\section{The social dimension to the 'NIMBY' syndrome}

The basis upon which to identify the social condition and specifics of the NIMBY syndrome was provided by survey research carried out on inhabitants engaged in nine conflicts ongoing in different parts of Poland. The conflicts selected most often revolved around major developments whose proposed location in rural areas drew protests. Two cases concerned wind farms, two cases roads, and there was one industrial-scale pig and poultry farm, one incinerator for municipal waste, one biogas plant and one mobile phone network mast. Specific locations proposed were in both the areas closer to cities (four cases) and more peripheral (five cases). In turn, the results of the work carried out allowed inter alia for the identification of inhabitants' most frequent fears connected with planned new developments, the scope of action taken and level of activeness it aroused among those protesting, and the influence on village life that the conflicts exerted.

In the light of answers inhabitants gave to questions concerning the negative and positive aspects of an unwanted development being located, it can be stated that the greatest fears revolve around possible odours, a fall in the value of property, threats posed to the natural environment, noise, and a negative influence on wellbeing and health (Fig. 5). We are thus dealing here with threats posed to the assets of inhabitants on the one hand (i.e. the value of property and their own health), and on the other hand with arguments relating to the safeguarding of such common goods as the quality of the environment in which people live. What links both kinds of argument is a desire on the part of the NIMBYists that their attitude should be understood, sympathised with and accepted by society as a whole, while the actions they take should bring the desired outcome. Such a strategy proves quite effective. The fears of those protesting are accepted by more than $3 / 4$ of people regarded as 'neutral' over a given matter, as well as - surprisingly - by almost $60 \%$ of those who actually support a given planned development. However, familiarity with the arguments applied by protesters is greater among supporters thereof $(79.4 \%)$ than among the neutral or impassive observers $(56.1 \%)$, given the latter's more limited involvement in ongoing conflicts.

The perceiving of potential threats translates into a series of actions taken by inhabitants wishing to prevent a burdensome new development from coming to fruition. The most typical forms of engagement in a conflict are: chatting - and then having campaign meetings with neighbours; offering words of support to those most active in the struggle against the unwanted new development, or else offering them assistance; seeking further information online or from other sources; and participation in rural meetings. In relation to the different cases, between $55 \%$ and almost $90 \%$ of respondents declared that they had taken part in this kind of activity (Fig. 6). Other forms requiring far greater commitment, and the devoting to the cause of extra hours and resources (including financial) were characteristic of far smaller proportions (between 10.6 and $16.3 \%$ ) of opponents. 
Figure 5: Average assessment of the negative and positive aspects of the locating of a planned new development, by people interviewed in the vicinity of their places of residence

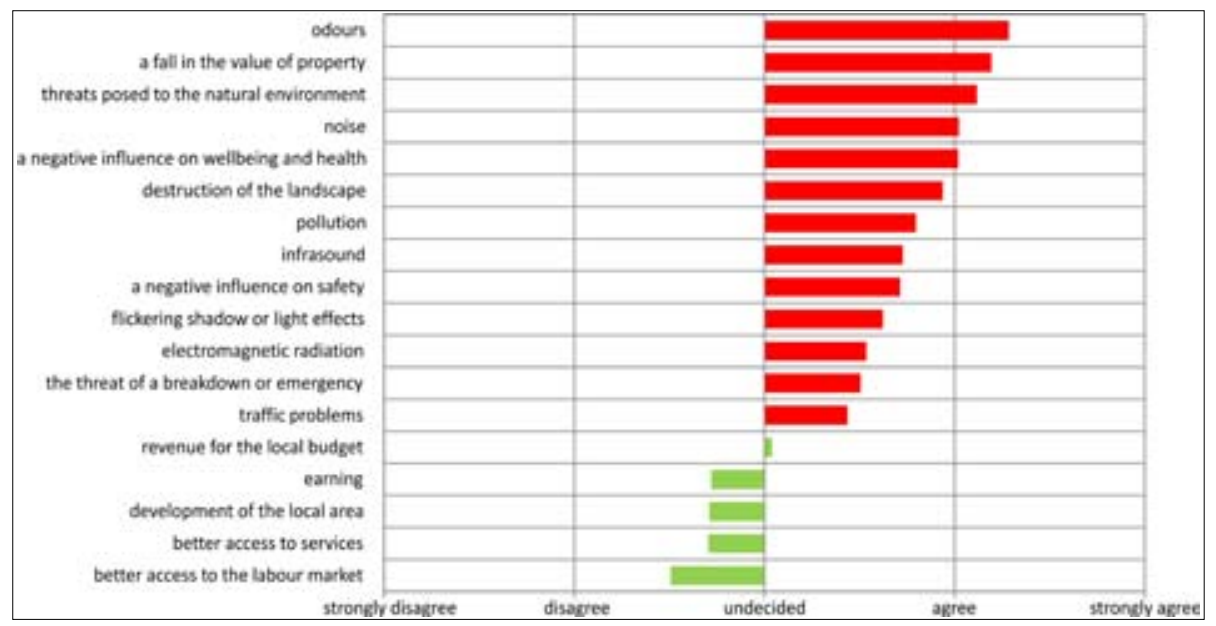

Source: author's own elaboration

Using statistics (i.e. Ward's method of cluster analysis) to analyse the breakdown of answers as regards activity taken up, it proved possible to identify three main types of attitude among opponents, corresponding with their level of involvement in the conflict. The first type was the very active person, representative of just $16.8 \%$ of all self-declared opponents. Most members of this notional group participated in all kinds of activity. These most active opponents became interested in the conflict (i.a. by talking with neighbours and looking for further information), participated in it actively (signing up to protests, taking part in meetings or protests), and even engaged in activity that sought to change the attitudes of others (by writing petitions, collecting signatures, distributing leaflets, meeting people beyond the gmina and joining an association).

A second group (largest in size) included $56.2 \%$ of opponents and comprised the moderately active, in that they showed considerable interest in the conflict ongoing around them and also signed up to protests, offered their help and took part in meetings with inhabitants, while not becoming very much involved in activity that would have required greater outlays of their own time, let alone financial outlays of their own money.

A last group accounts for around $27 \%$ of opponents, who were in essence inactive, despite their declared opposition to the construction of the unwanted new development. These inactive opponents only became interested in the matters of conflict to a very limited extent (beyond chatting with their neighbours), and they did not become involved in action either collective (meetings and petition-signings) or 
individual (petition-writing or the submission of remarks or applications in respect of planning documents).

Figure 6: Actions taken overall by protesters

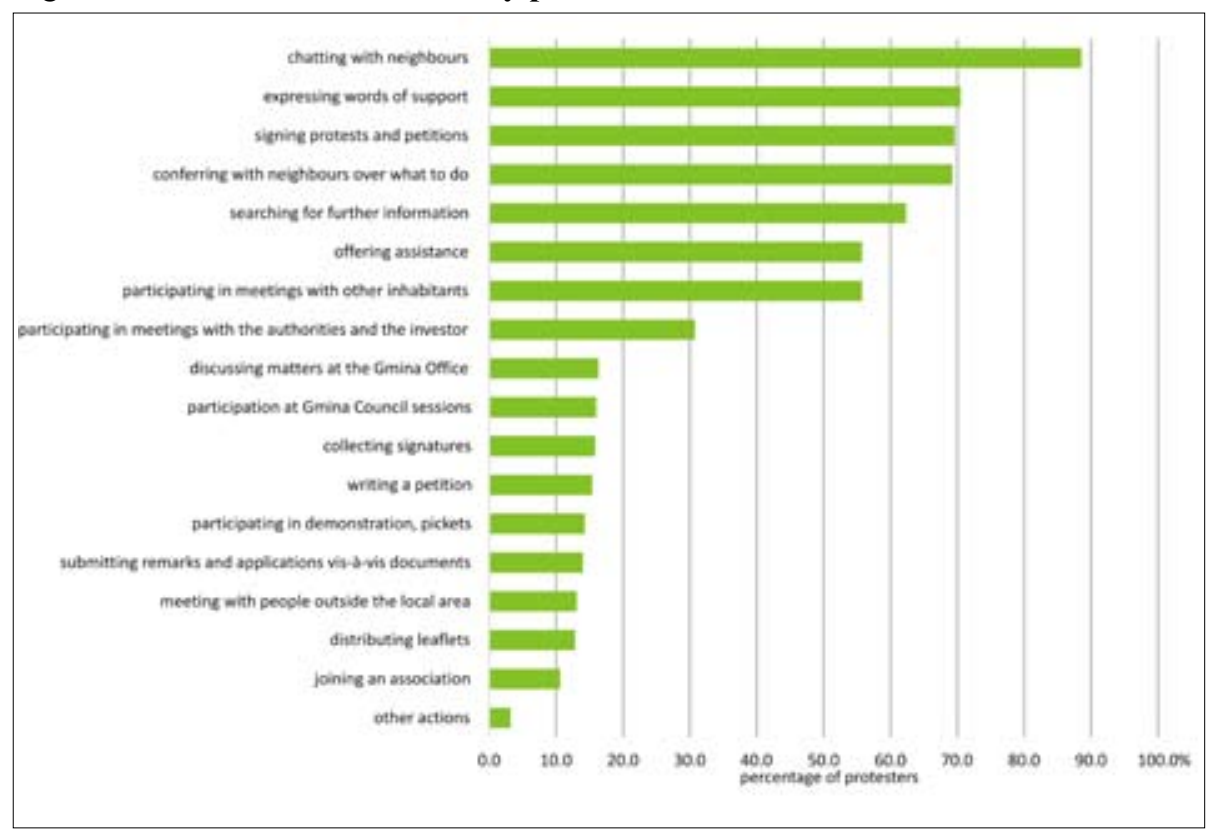

Source: author's own elaboration

A further characteristic feature of protest activity relates to the three levels on which it takes place, which is to say action of a persuasive, formal and legal or substantive nature. Where the persuasion dimension is concerned, the activity of protesters is directed towards the gathering of support capital from various different entities. In the case of the conflicts studied, this first and foremost entailed a search for allies among inhabitants, starting with neighbours, with these people needing to be informed about the problem and encouraged to swing behind planned protest. Meetings are organised for these people, leaflets are distributed among them and signatures are collected for petitions whose submission to decision makers is foreseen. The matter of the unwanted new development becomes a source of interest to a large group of inhabitants, who join in with it in various ways.

A typical outlining of the activity protesters engage in would also include the search for allies beyond local circles. Protesters make contact, and then cooperate, with institutions, organisations and communities beyond the confines of their own gminas. The problem is also trumpeted in the media. Protesters intervene with many 
institutions at regional, national or even European level, as well as embarking upon cooperative relationships with NGOs and communities engaging in similar protests elsewhere in Poland. A further 'rule' would be for conflicts arising in the areas around cities to entail leaders making more use than their counterparts in peripheral areas would of the Internet; the aim being to publicise the issue and make their opposition as widely known as possible.

Action of a formal and legal nature in turn entails participation in the administrative procedures leading to a new development being located officially. This means the submission of remarks and applications vis-a-vis the proceedings leading to the Environmental Decision, or else as regards draft planning documents, as well as filed appeals or complaints against unfavourable Decisions. All of these acts of formal participation exert a direct influence on the decision-making process. Involvement in the process by which allies are sought, and in the formal and legal sphere, is accompanied by activeness in the substantive dimension.

Those leading a protest seek substantively-motivated arguments by which to oppose a development, by studying the relevant documentation, seeking the opinions of experts and the results of research where impacts are concerned, and gaining greater familiarity with the natural resources present locally that make an area special. NIMBY-type conflicts always feature a war of words (and hopefully real arguments) between the investor and supporters of the new development on the one hand, and opponents on the other.

A further objective of the research was to assess the impacts of conflicts. An answer was sought for a question as to the role conflict plays in the lives of a local community, which mobilises to act against an unwanted or undesirable new development. Those surveyed declared that conflicts over the locating of a new development do much to influence their feelings as regards the value of the place they live in. From one locality to another, some $63-96 \%$ of respondents stated that the issue of a new development potentially being located in their area made them aware of just how valuable the place they reside in is. Only 3\% declared that the local conflict had no impact whatever on this. The conclusions drawn from qualitative research correspond with this idea. Conflicts were universally found to arouse debate locally as to the place of habitation and the threats it faced, or faces.

Questionnaires also made clear the influence the potential locating of an unwanted new development has, in encouraging a greater interest in public affairs generally, and in all that takes place in a given village or gmina. Nearly $80 \%$ of respondents said that a conflict had caused them to take a more lively interest in local issues. This also gained confirmation in the more in-depth interviews run with leaders of protests, among others. One of these pointed to an increase in the level of awareness among gmina inhabitants where participation in the planning process was concerned. "For example, we now know that, if some new investment process starts, it is up to us to demand public consultations. While these may not be obligatory for the authorities, 
inhabitants have the opportunity to speak up. And any attempts to suppress that are not allowed..."

A further effect of conflict (whether or not this ended in 'victory' for the given local community) was increased conviction as to the value and sense of the joint action taken. On average, about $80 \%$ of the residents in given localities claimed that they were now capable of engaging in joint action, which they saw as action well worth taking. The leader of one protest referred to the breaking-down of a certain barrier present previously in a local community: "We learnt to be courageous. People held their heads high. Let's put it straight: country-dwellers are not really courageous people. Simply, the comment 'and what will others say?' is familiar to all of us here. But at this moment, we see that people have stood up and stood out. They are saying 'No. We also have the right to something here.' Another added: 'People now feel more sure that they can actually do something'." It is therefore possible to come up with a thesis that the conflicts surrounding unwanted new developments can help build a feeling of enfranchisement and agency through a local community. That in turn allows us to hope that reinforced faith in the capabilities of one's own local community might manifest itself, not only as threats are battled against, but also as new quality is built and more use is made of arising opportunities.

Further positive consequences of conflicts can be said to include better relations in society. In different localities, between 12 and $42 \%$ of inhabitants claimed that the matter of an unwanted new development had allowed them to make new acquaintances in their village. At the same time, $8-33 \%$ declared that events linked with a conflict had increased the size of the pool of neighbours with whom they kept in touch.

The controversy and conflict surrounding an unwanted new development thus helps strengthen social capital of a binding nature (within people's own environment) and of a bridging nature. This was not the contribution of most declared opponents, but only of about $1 / 5$ of them. In the group surveyed, which had better-developed contacts with neighbours (social or based on mutual assistance), there was a greater share of those for whom the conflict resulted in an extending of their social network locally than was the case in the group of respondents whose neighbourly contacts were only poorly developed. At the same time, the group who had a wider group of known people beyond the area was characterised by a greater share of people for whom the conflict had provided for new acquaintanceship beyond the immediate area of residence than was the case among respondents with a smaller group of known people beyond the local environment. The building of new relationships was thus more of a factor for those who already had such ties quite well-developed.

Ongoing conflicts also exert their influence on local political life. Almost half of the opponents of a new development interviewed declared that the course of the conflict and the actions taken by leaders in the matter of the locating of an unwanted development had had an influence on the people they voted for in local government elections. For only $1 / 3$ of inhabitants had a conflict of this kind proved of no significance 
when it came to decision time at elections. Conflicts also forge new local leaders. Those leading protests against new developments later stand for election locally and most often win at least one Council seat. (In one of the localities researched the leader of one fight was elected to the post of village head or wójt at several consecutive elections.) The many associations set up in the course of conflicts often go on in the role of local opposition to authorities in power (even sometimes co-organising referenda to unseat a wójt or gmina council). At times, activity also transfers to other spheres of public life, like education, environmental protection or the safeguarding of heritage. In this aspect also, the influence of conflicts on community life can be evaluated positively, while the conflict itself can be said to have stimulated local communities into greater activeness.

\section{Conclusions}

The spatial dimension to the specifics of the NIMBY syndrome in the rural areas and small towns of Poland is first and foremost manifested in a concentration of this kind of conflict in the immediate surroundings of the country's largest cities. On the one hand, these areas are exposed to intensive investment activity (corresponding with a meeting of the needs of both the cities and the areas concerned themselves), while on the other they are characterised by a higher density of population, with a social structure more favourable to the initiation and emergence of conflict than in true rural areas, thanks for example to the population's (higher) level of education and of social activeness.

Furthermore, the complex and imperfect spatial planning system in Poland of itself ensures that many conflict situations will arise. The on-paper statutory guarantee of society's role in the process whereby new developments are located does not in fact allow for a real influence of communities, and is therefore very inclined to give rise to negative attitudes as regards planned developments, not least given inhabitants feeling that they are under-informed, or even simply being deliberately misled by the local authorities and/or investor-developer. The fears of inhabitants arise out of the potential threats, which (irrespective of the type of development) they feel may include unpleasant odours, a decline in the value of property, environmental threats and noise. On the other hand, the degree to which potential threats are 'sensed' by inhabitants has an impact on how actively they fight against unwanted new developments, as well as engage in, or commit to, campaigns against them. The actions such people take most frequently include conversing with neighbours, seeking out extra information on a proposed development, writing letters, signing petitions and engaging in various kinds of public protest. In parallel, a usually small group of leaders and most-committed people organise and put into effect actions that can see them assigning both time and their own financial means to the struggle. 
The NIMBY syndrome has both negative and positive consequences. On the one hand, there may of course be genuine negative influences of NIMBY developments should they be brought into being - on the natural environment, the landscape and the lives of local inhabitants. On the other hand, delays with the appearance of planned developments, or indeed their non-appearance, also have their negative effects from the financial point of view (not least the need to pay compensation and fines, the extra costs of relocating to another site, and so on). But then there is the way that the NIMBY syndrome makes people more aware of the value of the places in which they live, raises the level of interest of both individuals and communities in public affairs and in what goes on in a given village or gmina, and instils a conviction as to the value and sense of taking joint action. While a given NIMBY-type piece of new infrastructure either comes or does not come into existence, a strengthened feeling of local community and enfranchisement may often be a more-permanent effect of the conflict the proposal has given rise to, and one which translates into a building of the social capital present in local communities in rural areas.

\section{References}

BAŃSKI J., CZAPIEWSKI K. (2009), Obszary o znaczącym endogenicznym potencjale rozwojowym. In: BAŃSKI J. (ed.), Analiza zróżnicowania i perspektyw rozwoju obszarów wiejskich w Polsce do 2015 roku (= Studia Obszarów Wiejskich, 16), pp. 55-74. Warszawa, Komisja Obszarów Wiejskich Polskiego Towarzystwa Geograficznego, Instytut Geografii i Przestrzennego Zagospodarowania PAN.

Bell D., Gray T., Haggett C. (2005), The 'social gap' in wind farm siting decisions: explanations and policy responses. In: Environmental Politics, 14, 4, pp. 460-477.

Burningham K., Barnett J., Thrush T. (2006), The limitations of the NiMBY concept for understanding public engagement with renewable energy technologies: a literaturę review. $<$ http://geography.exeter.ac.uk/beyond_nimbyism/deliverables/bn_wp1_3.pdf; 02.2016>

Caplan A., Grijalva T., Jackson-Smith D. (2007), Using choice question formats to determine compensable values: The case of a landfill-siting process. In: Ecological Economics, 60, pp. 834-846.

Devine-Wright P. (2005), Beyond NIMBYism: towards an integrated framework for understanding public perceptions of wind energy. In: Wind Energy, 8, pp. 125-139.

Fredriksson G. (2000), The Siting of Hazardous Waste Facilities in Federal Systems. In: Environmental and Resource Economics, 15, pp. 75-87.

GrocholsKa J. (1980), Obszary konfliktowe - problem badawczy w przestrzennym zagospodarowaniu kraju. In: Przegląd Geograficzny, 52, pp. 507-515.

GrocholsKa J. (1986), Konflikty w planowaniu przestrzennym i próby ich rozwiązania (na przykładzie wybranych obszarów aglomeracji warszawskiej) (= Studia nad funkcjonalnym makroregionem Warszawy, III). In: Biuletyn Informacyjny, 53, pp. 205-222.

Groeger L. (2009), Aspekt społeczny w kształtowaniu przestrzeni mieszkaniowej. In: SpaceSociety-Economy, 9, pp. 71-89. 
Hermansson H. (2007), The Ethics of NIMBY Conflicts. In: Ethical Theory and Moral Practice, 10 , pp. 23-34.

KoŁodzIEJSKi J. (1982a), Geneza, funkcjonowanie oraz ocena sytuacji konfliktowych w gospodarce przestrzennej Polski. In: Diagnoza stanu gospodarki przestrzennej Polski, „Biuletyn KPZK PAN”, 123, pp. 134-148.

KoŁodzIEJSKi J. (1982b), Realizacja celów rozwoju w warunkach narastania konfliktów w gospodarce przestrzennej. In: Konflikty polskiej przestrzeni, „Biuletyn KPZK PAN”, 120, pp. 7-51.

Kopeć A. (2009), Udział społeczny w planowaniu przestrzennym - uwarunkowania prawne a praktyka planistyczna. In: Space-Society-Economy, 9, pp. 35-42.

Lesbirel S., Shaw D. (2000), Facility Siting: Issues and Perspectives. In: Lesbirel S., Shaw D. (eds.), Challenges and Issues in Facility Siting: Conference Proceedings, pp. 1-14. New York, Columbia University Press.

LeVInson A. (1999), NIMBY taxes matter: the case of state hazardous waste disposal taxes. In: Journal of Public Economics, 74, pp. 31-51.

Livezey E.T. (1980), Hazardous waste. In: The Christian Science Monitor, 11.6.1980. <http:// www.csmonitor.com/1980/1106/110653.html; 02.2016>

Minehart D. (2002), Effective Siting of Waste Treatement Facilities. In: Journal of Environmental Economics and Management, 43, pp. 303-324.

Rahardyan B., Matsuto T., Kakuta Y., Tanaka N. (2004), Resident's concerns and attitudes towards Solid Waste Management facilities. In: Waste Management, 24, 5, pp. 437-451.

Rosner A., StAnNy M., (2007), Zróżnicowanie poziomu rozwoju obszarów wiejskich w Polsce według komponentu społecznego. In: RosNer A. (ed.), Zróżnicowanie poziomu rozwoju społeczno-gospodarczego obszarów wiejskich a zróżnicowanie dynamiki przemian, pp. 115-152. Warszawa, IRWiR PAN.

Schively C. (2007), Understanding the NIMBY and LULU Phenomena: Reassessing Our Knowledge Base and Informing Future Research. In: Journal of Planning Literature, 21, pp. 255-266.

SIEMIŃSKI W. (2007), Cele i zasady partycypacji społecznej w planowaniu przestrzennym przegląd literatury. In: Człowiek i Środowisko, 31, 1-2, pp. 37-59.

TAKahashi L.M., Dear M.J. (1997), The changing dynamics of community opposition to human service facilities. In: Journal of American Planning Association, 63, 1, pp. 79-93.

VAN DER HORST D. (2007), NIMBY or not? Exploring the relevance of location and the politics of voiced opinions in renewable energy siting controversies. In: Energy Policy, 35, pp. 2705-2714.

WoLsINK M. (2000), Wind power and the NIMBY-myth: institutional capacity and the limited significance of public support. In: Renewable Energy, 21, pp. 49-64.

Wóscik M., DmochowsKa-Dudek K., Traczyk A. (2014), Konflikty społeczno-przestrzenne na obszarach wiejskich województwa łódzkiego. In: Biuletyn Krajowej Sieci Obszarów Wiejskich Województwa Łódzkiego, 4, pp. 8-11.

Wóıcıк M. (2013), Przemiany społeczno-przestrzenne osiedli wiejskich. Studium przypadku Łódzkiego Obszaru Metropolitalnego. Łódź, Wydawnictwo Uniwersytetu Łódzkiego. 
